\title{
SHALL TRAINING SCHOOLS FOR NURSES BE ENDOWED?
}

AN ADDRESS DELIVERED BEFORE THE TRAINING SCHOOL FOR NURSES OF LAKESIDE Bospital, Cleveland, MAY 11, 1906, BY HENRY M. HURD, M.D., SUPT. THE JOHNS HOPKINS hOSPITAL AND PROFESSOR OF PSYCHIATRY, JOHNS HOPKINS UNIVERSITY.

THE modern training school for nurses owed its origin, as has often been repeated, to the charitable impulses of devoted women who wished to acquire a knowledge of the best way to nurse the sick and to impart this knowledge to others. As the art of nursing had no definite beginning-it simply grew-so it may be said without in any manner seeming to undervalue its importance that the work of the training school was not originally fostered and developed for its value as a means of education or mental training, but rather as a species of handicraft. Some persons engaged in the care of the sick in certain hospitals or institutions had evolved through observation and experience fixed methods of nursing which they taught to others, who in turn practiced them until, through many repetitions, they had become proficient in them, just as housekeeping, spinning, weaving, and other domestic arts were taught to our ancestors a century ago, not from precept or from text-books, but by example and often strictly in accordance with precedent. It was sufficient to know that certain procedures had been found useful in the care of the sick, and that they had the warrant of long-established usage for their continued employment; they were accepted as orthodox and there was little disposition to call in question their superiority or to modify them as the result of any spirit of inquiry or through skepticism as to their intrinsic value born of the scientific spirit. Great comfort to the sick has followed the pursuit of nursing simply as a handicraft, and many there are-principally those whose faces are set towards the setting rather than the rising sun-who still lament that the methods of instruction in nursing did not continue to be manual as of a handicraft rather than educational as of a profession. Handicraft concerns itself most in learning the way in which some other person has performed a given piece of work, and generally considers facility in doing it. Education, on the other hand, gives good reasons for doing the task in a specified way, and teaches the principles which underlie any proper method of accomplishing it, and which may be effective in the future, and thus enable one to meet an unexpected emergency or cope with a new difficulty. Manual 
dexterity or handicraft renders one skilful to do what some one before you has already done; education in the principles of an art renders one resourceful in the face of new problems and fits one to assume unexpected burdens. I have no desire to minimize the importance of manual training or to be classed among those who would train the head rather than the hand. Manual training has, however, been sufficiently emphasized in our modern educational methods, and needs no elaborate advocacy at the present time. It is interesting to note how, even at this time, the ancient contention among the Greeks as to the value of the liberal as opposed to the practical arts is constantly reappearing. Plato declared that arts like music, literature, mathematics, and philosophy were liberal arts because, as he believed, through their study it was "easier for one to see the good and to realize its perfection" than through the study of practical arts. These so-called liberal arts were avowedly without any practical outcome. They were woven out of the imagination or were the results of abstract philosophical speculation, and their pursuit was a purely intellectual one. Those who followed them always manifested a degree of condescension towards those who practiced the proctical or technical arts. This distinction has gone through the educational systems of every people for many centuries, and the last word has not been uttered concerning them even yet. It has been impossible for many minds to conceive that theory and practice may be combined, and that the best way to see the beautiful and good and to realize their perfection is to give the beautiful and good a concrete form in noble, philanthropic acts to develop civilization and uplift the race.

It is related in a university town that a distinguished mathematician was once approached by a talkative lady with an inquiring mind, who asked him to tell her all about the practical utility of higher mathematics, and received the rather unsatisfactory reply, "Thank God, madam, it has no practical use." Such a conception of knowledge may be of the highest interest to a mathematical genius, but to an ordinary person a science or an art which has some practical utility appeals much more strongly than one which exists wholly in the realm of imaginative speculation and never comes down to earth.

In the evolution of nursing we see a happy combination of liberal knowledge and practical experience. The mind of the nurse is instructed to perceive the bearing of scientific laws and to apply them to the better care of the sick; the hand is taught to do, the eye to see, and the ear to hear. We used to hear much of the qualities of the natural physician, the natural musician, the born artist, and the 
born nurse. Unquestionably many people have a special aptitude for special employments, but no one can make aptitude a substitute for mental training. A natural qualification of the eye and of the hand, and of every sense, is most desirable in any calling, but an acquired qualification of the mind is equally essential, because it renders possible a proper coördination of every faculty.

In the adnirable little book of Professor Allbutt, he utters words in reference to medical education which may with equal force be applied to all education. He says: "In the minds of academical teachers the notion still survives that the theoretical or university form and the practical or technical form of a profession, or, rather, calling, may not only be regarded separately and taught in some distinction-which may be true-but in independence of each other; nay, that the intrusion of a technical quality by materializing tends to degrade the purity or liberality of the theoretical; that, indeed, if he have not to get his daily bread, the high-minded student may do well to let the shop severely alone. Thus the university is prone to make of education thought without hands; the technical school, hands without thought; each fighting shy of the other. But if in a liberal training the sciences must be taught whereby the crafts are interpreted, economized, and developed, no less do the crafts by finding ever new problems and tests of science inseminate and inform them, as in our day physics have been informed and fertilized by the fine craft of such men as Helmholtz, Cornu, and Stokes; or biology by that of Darwin, Virchow, Pasteur, and Lister." He says further: "There exists, no doubt, the opposite danger of reducing education to the narrow ideas and stationary habits of the mere artisan. By stereotyped methods, the shop-master who does not see beyond his nose may cramp the prentice; and the prentice becomes shop-master in turn. If in the feudal times, and times like them in this respect, manual craft was despised and the whole reason of man was driven into the attenuated spray of abstract ingenuity, in other times or parts of society a heavy plod of manual habit had so thickened 'the nimble spirits in the arteries,' that man was little better than a beaver: on the one side matter, gross and blockish; on the other, speculation, vacuous of all touch of nature. We need sorely the elevation, the breadth, the disinterestedness, the imagination, which universities create and maintain; but in universities we need bridges in every parish between the provinces of craft and thought. Our purpose must be to obtain the blend of craft and thought which on the one hand delivers us from a creeping empiricism, on the other from exorbitant ratiocinations." 
There still exists a survival of archaic ideas in regard to nursing. Nursing the sick in this country at least owed its origin to the humane impulses which lead the well to care for the sick. In country places or pioneer life the duty of sitting up with the sick at night had always been regarded a sacred one, and friends and neighbors had ever been prompt to respond to the call. When the immediate family became worn out by the care of a case of prolonged illness, the same persons responded to the summons by night and by day, even to the neglect of their own daily avocations. The mother also at all times was the natural nurse of the family. As she did not engage in the exhausting toil of the field or of the farm, she was often able to combine the care of the sick with her household duties. Hence, as was natural, the early theory of nursing contemplated that an individual should perfect herself in the work by practice, and there was little thought of the need of any higher education. For this reason, when training schools were established the period of training was comparatively brief. The first training schools, in fact, had periods of training of less than a year, and even then the instruction afforded was primitive and meagre. With the advent, however, of antiseptic surgery, due to a knowledge of the germ theory of disease, the discoveries of bacteriology, and the advances in the field of preventive medicine, it became apparent to all that nursing could no longer continue to be a handicraft and a merely practical service. It was essential that the nurse should understand the principles which were enlightening her work; that she should know why certain procedures had been adopted, and why they were absolutely essential. The rule of thumb could no longer be practiced in nursing. The nurse must become a thinking, reasoning person, able not only to follow precedent, but fully equipped to reason from established principles and resourceful to meet emergencies. This necessitated an extension of the period of study, a systematic course of instruction, and a greater complexity and thoroughness of training. The period of study, which had been less than one year, grew to two years, and finally in the best training schools it has been extended to three years. It also became painfully evident that many pupils who offered themselves for instruction were not prepared by previous training to profit by it. Many of them did not have an adequate general education, and, besides, they lacked special knowledge of housekeeping, cooking, dietetics, and an elementary knowledge even of the sciences which underlie all the work of the nurse. In consequence of these educational deficiencies among applicants, a preliminary course of instruction has been arranged in some of our training schools, for the purpose of giving nurses an ele- 
mentary knowledge of physiology, anatomy, and hygiene, and a practical knowledge of cooking, bandaging, the care of the room, and the personal care of patients, before admitting them to the wards and giving them responsible duties in the nursing of the sick. These higher standards of instruction and lengthened periods of training have vastly increased the expenses of training schools. Haphazard instruction, such as was formerly given by lectures from members of the medical or nursing staff, who often had little knowledge how to teach or what to teach most effectively, has been replaced in some measure by systematic instruction given by paid teachers. Instruction in household economics, dietetics, cooking, anatomy, physiology, hygiene, massage, and pharmacology, in whole or in part, has now in many schools been placed in the hands of salaried teachers, the clinical branches alone being committed to the medical staff. Similar instruction in the practical duties of the nurse has been committed to persons selected to teach because of proper knowledge and an aptitude for teaching. Such schools have been placed upon the footing of educational institutions, and while they have relinquished none of their excellence, and have sacrificed none of their practical functions as trainers of thoroughly equipped nurses, but have rather increased them, they have ceased to be mere manual training schools.

As in the past, so now training schools for nurses suffer from an imperfect appreciation of their true scope on the part of their promoters and of the public generally. In the past, owing to the lack of any endowment or proper means of support for training schools, in many instances it was customary to send nurses out into the community during their period of training to earn money for the school in order to maintain it. The position of the nurse thus sent away from the school was akin to that of the tourist in the Cannibal Islands, who, when he was welcomed to a feast, found to his surprise that he was personally expected to furnish the meal. The effect of such a practice has been altogether bad. The nurse doubtless learns something of human nature by these semi-charitable excursions into the homes of the well-to-do, but she loses far more than she gains. Orderly, systematic instruction under competent supervision is impossible. A nurse engrossed in the care of a very ill patient in a family at a distance from the hospital cannot attend class exercises or pursue her studies to any advantage. She gets an impression, moreover, that her class work and proper instruction in her duties are secondary considerations, and that the chief part of her training is her practical work. Furthermore, the poverty of the school and the withdrawal of many nurses necessitate excessive 
hours of work for the inadequate staff which remains. There are never too many nurses for the work of an active hospital, and if hospitals like these are to be adequately nursed, those who remain behind must work over-hours. The position of the pupil nurse is a deplorable one. Deprived of capacity to acquire knowledge by reason of fatigue and nervous exhaustion, she cannot profit even by the meagre and imperfect instruction which under more favorable circumstances she might secure. Another and more deplorable feature is the overemphasis which is thus laid upon the commercial side of nursing. Nursing is no longer viewed as a profession to be acquired through education and hard study, but a trade to be pursued solely with a view to getting a living. It is but natural that a nurse should feel that theoretical instruction is of little value when it is the custom of the hospital and training school to interrupt her education at any time to send her out to attend to patients in no way connected with the school, or when the nurse is kept away from her studies and class-room by the excessive demands of the hospital upon her time. It is well known that no first-class school of any sort, and no form of higher education, can be a profitable business enterprise; that the teaching of theology, of law, medicine, and of pedagogics, or instruction in the strictly technical schools, cannot rest upon a commercial basis and pay its proper expenses. It should ever be borne in mind that nursing the sick is now a calling, as much as law, medicine, or theology; that it enters into the life of the community to a greater extent even than these professions, and that the families of the rich equally with the poor are concerned in the proper education and training of nurses.

The experience of our medical schools is of interest in this connection, as showing how it is now impossible to conduct a first-class school as a conmercial venture. Formerly, when medicine was taught by lectures, and students were instructed en masse, it was possible to secure an ample and one might truthfully say an excessive compensation from students for the instruction given. There were no outlays for laboratories, and no arrangements for clinical teaching. Physiology, pathology, clinical microscopy; pharmacology, physiological chemistry, histology. and embryology were unknown, or their teaching was ignored. They had few salaried instructors, little apparatus beyond a simple chemical outfit, and no bedside instruction. This is now changed, and the old-fashioned medical school finds that it must transform itself into a true educational institution, with many laboratories and much expensive apparatus for teaching, or go out of business. Falstaff's fatal disease, "Consumption of the purse," is inevitable with many of them. 
The medical schools which remain in commission must have an ample endowment to place medical elucation upon a proper footing and do good educational work. It is equally true that a similar endowment is necessary for the training schools for nurses. The duty is apparent. To the nurse is committed the personal care of the sick in every community; she comes into the family; she bears the responsibility and care of the family in the absence of the family physician; she represents him, replaces him, assists him, and supplements his labors by her efficiency and helpfulness. Through her efforts his labors to cure his patients are made effective. If she is imperfectly trained and unable to appreciate the higher range of her duties, she becomes a broken reed, upon which he cannot lean with safety.

Then, too, in the more public duties of the nurse an adequate training is equally essential. In every city, large or small-nay, in every village or town-the hospital, with its properly arranged, well equipped operating room, efficiently supervised by a trained nurse, has become essential, so that an accident case, or one requiring sudden surgical intervention, can be cared for as speedily and as well at the home of the patient, wherever that may be, as in the largest city clinic or the most expensive hospital in the land. The competent and thoroughly trained nurse is an all-important adjunct of every such hospital.

The nurse has also been introduced into the public school, with great advantage to the public welfare. She watches over the health of the pupils; she observes the hygrenic condition of the school; she visits the home to know how the pupils live there, and to give such instruction as will improve the conditions of living. In district nursing her services also require the highest grade of intelligence and training. She must become, to use Florence Nightingale's term, "a missioner of health" to families of the poor, and must preach the gospel of hygienic living and healthful surroundings.

Upon the tuberculosis nurse is placed the hardest part of the battle which is being waged against tuberculosis in every part of the country. She not only must look after the sick as a nurse, but also is responsible for the hygienic care of the sick and the instruction of the family, so that tuberculosis may not be a source of danger to the community. She must equally instruct the family and supervise the home, so that other members of the family may not, through inadvertence or ignorance, acquire the dread disease. She must see that families live healthily; that too many are not crowded into an infected room; that rooms are properly disinfected after the death or removal of a tubercular patient, and must protect the whole community from the spread of tuberculous disease. 
When such important duties devolve upon the trained nurse, it is short-sighted in the extreme and contrary to good policy to leave the establishment and maintenance of training schools to private initiative, where too often the governing motive must be to get public or private hospitals supplied with nurses at the lowest cost to the institution.

Is it not the duty of the public rather, for its own welfare, to see that nurses' training schools are adequately endowed, so that young women of character and ability can be induced to come to them, and so that when they come to such training schools they may be properly instructed for the discharge of duties which take hold of the health and welfare of the entire community?

I deen it a high privilege and honor to be called to address you at this time. In the comparatively brief career of Lakeside Hospital its reputation has extended to other cities and has incited other communities to good works. The Hospital and its Training School have stood for thorough, faithful work. Those who founded them laid substantial foundations and built wisely upon them. Expert advice has always been sought, and the Hospital and the Training School have profited by them. No one can esteem too highly the influence of such a hospital and such a school upon the public welfare. They have served in the past and will continue to serve as models for the guidance of other similar institutions in Cleveland and in other cities. The reflex influence for good also upon those who have felt the responsibility of their maintenance and perfection cannot be overestimated. A city which thus endows hospitals and training schools for nurses and supports them demonstrates anew the growing sense of the responsibility those should feel who have wealth. Large wealth is indeed a trust for the public welfare, not a possession for private gratification and individual luxury. The hope of the American people is largely centered around the proper maintenance of these and similar institutions. What would the history of Boston have been during the past century had the Massachusetts General Hospital and the City Hospital never been erected? Who oan estimate how much these institutions have done for the public welfare, and how much more for the education of the wealthy in the proper use of their abundance? How large a place in the municipal life of New York City has been taken by the New York Hospital, Roosevelt Hospital, St. Luke's Hospital, and the Presbyterian Hospital. Similarly, in Philadelphia. Can the influence of the Pennsylvania Hospital, founded by the efforts of Benjamin Franklin and perpetuated by a long line of worthy philanthropists who have succeeded him, 
upon the development of the spirit of charity in that city be summed up in words? In my own city, the foundations which bear the name of Johns Hopkins have made an impression upon the whole city, and not alone upon the profession of medicine. The intellectual development of the whole country has been quickened and energized by the example of wealth dedicated to higher uses. We are told that the example of George Peabody directly influenced Johns Hopkins. So, in turn, the example of Johns Hopkins has similarly influenced many others, until the widening circle of influence has extended over the whole land. The liberal endowment of a school for nurses here or in New York or Philadelphia or Boston or Baltimore nust prove equally beneficial to the profession of nursing throughout the United States.

A well-known writer has published an interesting and suggestive book to show that the law of mutual aid as opposed to the more generally accepted law of competition and constant struggle has been a potent factor in the evolution first of the animal kingdom and of man, and afterwards equally in the evolution of human institutions. He fortifies his contention by many novel and interesting facts drawn from nature. He describes how land crabs assist each other in the event of an accident or sudden calamity, going so far as to station sentinels to protect moulting crabs, who are at this time helpless to protect themselves; how the worker ant carries the lame, feeds the hungry or exhausted, cares for the lazy or incompetent, and labors assiduously and unselfishly for the general good; how the honey bee rejoices in a life of servitude and self-denial to upbuild the community, without the smallest regard for the individual; and how birds of prey like the eagle, the hawk, and the vulture band themselves together for mutual protection and assistance. They seek their food together, warn each other of danger, notify one another of the presence of prey, and share with each other the product of the chase. Beavers, it is well known, in community life undertake great public works for mutual benefit, and their whole existence depends upon a complete harmony of action and mutual assistance in providing food and shelter. Even horses and cattle, now the most individual of our domestic animals, in a wild state lead an associated rather than an isolated life, and protect each other and their young, often at the cost of much individual suffering, distress, and death. The same holds good among barbarous peoples, and even among savages. The law of mutual help, the law of hospitality, the care of the aged, the protection of the weak-all these forms of personal service exist in a rudimentary form in the lowest civilizations. As we rise in the 
scale, the degree to which one helps another increases, until mutual effort by all for the welfare of the whole community has come to be regarded as a universal law of society. This has been most clearly and forcibly expressed by St. Paul, when he says: "We then that are strong ought to bear the burdens of the weak and not to please ourselves." There can be no higher form of mutual assistance than the personal service rendered by the trained nurse in the hospital, as a district nurse, as a tuberculosis nurse, in the public schools, in the social settlement, in the army and navy in the Red Cross, in the home of the poor or the palace of the rich. Everywhere her presence makes for comfort in sickness, for the minimization of the loss to the community and the state which disease, suffering, and death entail, for the prevention of disease, and for the social uplift which is the hope of the nation, with its conglomerate population and racial diversities and animosities. More surely than education alone, more strongly than the ties of religion, more firmly than self-interest and commercialism, this form of service will bind society together and assist each class in the effort to lighten the burdens of the other.

And now a word of apology to the graduating class, which I have neglected too long. I have already trespassed too much upon your patience, and have little time for the advice which usually flows so freely upon these occasions. If I have no great amount to proffer, it is because I feel that to-day should rather be one of congratulation. You have studied diligently and labored industriously during your period of training, and you are to be felicitated upon having gained what you have striven for. "Earnest toil and strong endeavor" are beneficial to those who are developing characters, it is true, but accomplishment is no less so. We are developed also by attainment and success, and are fitted to attempt greater deeds.

I would impress upon you, as forcibly as I can, the great need in every community of personal, intelligent service to relieve sickness, suffering, and distress, and to better social conditions. You have been specially trained for this service, and are peculiarly equipped to do efficient work. Much has been done for you, and you have done much for yourselves. We have a right to expect much from your initial fitness for the work of nursing, and your excellent training. Your chosen calling is not, primarily, an opportunity to open the world's richest oyster or to shake the golden plum tree of worldly success. It is rather the privilege to minister to suffering, to help every philanthropic enterprise, and to assist in the betterment of the masses.

I would impress upon you the need of accurate and available 
knowledge. Continue your habits of reading and study, and study with open eyes and receptive and retentive minds. An American politician (some called hin a statesman) once said, "I thank the Lord that the things which I know I know, anywhere at any time." Of a recently appointed English cabinet minister it is said, "His mind is not an attic littered with odds and ends mainly for rainyday service and reniniscence, but a well-ordered store-house filled with seasoned dimension stuff and ready for instant construction." A few days ago I heard a witty divine divide physicians into two classes, those on the one hand who are so engrossed in study as to be unable to do any practice, and those on the other who are so busy with practice that they never study at all. Seek a happy mean between these tro conditions. Forn habits of study, keep pace with the improvenents in nursing, take the journals of your calling, and not only read but contribute to them. Continue to educate yourselves, and aroid any retrogression in your work, such as will otherwise be inevitable. I have no fear that nurses will ever be overeducated or over-trained. Finowledge is power, and the fuller the knowledge and the better the training of a good nurse, the greater her power.

Every nurse should have a hobby to ride for recreation and exercise in the intervals of her severer duties. This can be almost anything which is not associated with her work as a nurse, such as dabbling in water colors, writing poetry, collecting old books, painting china, gathering cigar bands or stamps or old coins or antique furniture. Whatever the hobby or fad may be, it should be ridden faithfully and with enthusiasm, but also with discretion; the nurse should retain a firm seat and master the hobby and not be controlled by it. This diversion will be a safety-valve if one is inclined to live at too high a rate of pressure, and may possibly avert a catastrophe. Do not take your life as a nurse too seriously. Be content with doing your full duty in all you attempt to do; bear constantly in mind that impossibilities are not expected of any persons-except possibly hospital officers and trustees. They should be able to work miracles. Be calm when you have done your best, and cease to worry over what cannot be helped.

Learn to be cheerful, happy, hopeful, and enthusiastic workers. Pessimism and a spirit of complaint never accomplished any good and never can.

In the name of the profession of medicine, and in behalf of its members, I welcome you and bid you God speed! 